\title{
Artikel
}

\section{Het papieren paleis}

Prof. dr. J.M. (Maurits) Barendrecht en M. (Maurits) Chabot*

\section{Inleiding}

In 2013 rijdt een Poolse automobilist diep in Brabant over een tweebaansweg. Hij mist een flauwe bocht en raakt twee grootouders en hun tweejarige kleindochter, Ize Derijks, die naast de weg fietsen. De grootouders en het kleinkind zijn op slag dood. De zaak krijgt veel media-aandacht als Erik Derijks, de vader van Ize, een stoel naar de rechter gooit terwijl ze de veroordeling voorleest. Zijn schoonvader, schoonmoeder en dochter zijn dood, en de verdachte krijgt een taakstraf van honderdtwintig uur. In een interview met het AD vertelt de vader dat hij stijf stond van de adrenaline en zichzelf niet onder controle had. Hij hoopte tijdens de rechtszaak op een teken van berouw, maar de automobilist beriep zich op zijn zwijgrecht. Tijdens het anderhalf jaar durende proces toonde de verdachte geen enkele emotie. De ouders van Ize verwachtten daarna op zijn minst een celstraf, zodat de automobilist de tijd zou krijgen om tot bezinning te komen en te beseffen wat hij had aangericht.

De rechter las het vonnis zakelijk en afstandelijk voor. Ze maakte geen oogcontact met de ouders en vertelde dat niet bewezen kon worden of de automobilist te hard had gereden. Er viel op basis van het politieonderzoek te weinig over de toedracht vast te stellen. Omdat de verdachte nooit een verklaring had afgelegd, kon de rechter niet reconstrueren wat er gebeurd was. Het drama werd teruggebracht tot een lichte verkeersovertreding en zodoende kreeg de automobilist een taakstraf. De rechtszaak was voor de ouders van Ize een deceptie.

Maurits Barendrecht (1956) is hoogleraar innovatie van rechtssystemen Tilburg University en directeur onderzoek en ontwikkeling bij HiiL. Maurits Chabot (1992) is historicus en journalist bij de Volkskrant.

\section{Strafrechtspraak sluit niet aan op strafdoelen}

De zaak van de familie Derijks is slechts één van de vele zaken die de vraag oproepen in hoeverre onze strafrechtspraak effectief is. Doen we recht aan de wensen van slachtoffers, de noden van veroorzakers en de behoeften van de samenleving? Het strijdmodel van de rechtspraak lijkt daar slecht bij aan te sluiten. Hoeveel waarde heeft een veroordeling als de verdachte ontkent en geen verantwoordelijkheid neemt? Voelen mensen zich gehoord, begrepen en gezien? Komen corona-ontkenners, veelplegers van overvallen of psychopaten zo op een beter pad? Is dit de beste manier om de strafdoelen te bereiken?

\section{Zwaarder straffen: een misverstand}

Tussen de strafdoelen zit spanning. Die brengt ons snel bij de roep om zware straffen. Die klinkt vaak luid, ook na de zaak van de familie Derijks. Het is een wijdverspreide gedachte dat onderzoek aantoont dat mensen hogere straffen eisen en dat de behoefte aan vergelding niet wordt vervuld. Maar de vraag die onderzoekers stellen, vertekent het resultaat. Als je mensen vraagt of rechters zwaar genoeg straffen, bied je ze een eenzijdige keuze: ofwel laten zoals het is, ofwel harder ingrijpen. Als harder straffen de enige optie is, ligt het voor de hand dat mensen daarmee instemmen. Ze beseffen heel goed dat enkel hard straffen niet werkt, maar als hun slechts één middel wordt geboden om iets te bereiken, doen ze liever meer van iets wat niet goed werkt, dan helemaal niets. 
Het beeld verandert als ze meer opties krijgen. In een door Amerikaanse onderzoekers opgezet experiment konden mensen duizend dollar besteden aan de bestrijding van criminaliteit. Ze mochten kiezen uit meer gevangenissen, meer verslavingsbehandelingen, meer politie op straat of meer preventieprogramma's om jongeren uit de problemen te houden. Wat bleek: de twaalfhonderd respondenten gaven het meest uit aan preventie (366 dollar). Daarna volgden meer behandelingen (221 dollar) en meer politie op straat (210 dollar). Aan zaken waardoor zwaardere straffen bereikt kunnen worden, besteedden de proefpersonen minder, zoals aan meer gevangenissen (gemiddeld slechts 84 dollar). Een verrassend resultaat. Vele onderzoeken wijzen uit dat mensen willen dat er meer aandacht gaat naar compensatieregelingen, psychologische hulp en re-integratietrajecten. Naar preventie in plaats van vergelding. Maar zolang alleen straf op het menu staat, zullen ondervraagden geneigd zijn daar nog maar een extra portie van te bestellen.

\section{En de georganiseerde misdaad dan?}

Willem Holleeder wordt geen tomatenteler als hij in het Westland een moestuin krijgt. Er zijn zaken die je niet oplost met herstelrecht en effectieve reclasseringsmaatregelen. Soms is het ook hard tegen hard. De veelgehoorde consensus: mediation heeft veel in haar mars; het beteugelen van georganiseerde misdaad moet via het Wetboek van Strafvordering. Maar nee, ook daar biedt het huidige strijdmodel geen oplossing.

Het is geen sinecure om kopstukken van criminele netwerken voor de rechter te slepen. Criminelen opereren geraffineerd en zijn meester in het verhullen van hun activiteiten. Loopjongens zijn actief in de frontlinie van hun praktijken terwijl de opdrachtgevers behoedzaam op de achtergrond blijven. De juridische weg om hen te pakken te krijgen is moeizaam en frustrerend. In de rechtszaal komt zo'n kopstuk na vele jaren individueel in het beklaagdenbankje. Een voor een leggen de bendeleden verantwoording af. Ze kunnen zich verschuilen achter hun zwijgrecht en hun advocaat twijfel laten zaaien over de betrouwbaarheid van getuigen. Ze hoeven niet te vertellen hoe het dan wel zit. Onschuld is een belangrijk uitgangspunt. Bij een spoortje twijfel volgt vrijspraak, dat is wat de strafrechters is ingepeperd.

Procedureel is er te veel om over te debatteren. Officier van justitie Greetje Bos, ruim veertien jaar officier van justitie, liet in 2017 in de Volkskrant optekenen dat het strafrecht faalt bij de bestrijding van georganiseerde (drugs)criminaliteit. Volgens haar is het strafproces niets minder dan een 'logistieke nachtmerrie', waarbij verdachten steeds vaker ontkomen aan een straf en advocaten processen tot in den treure vertragen. 'Weet je hoeveel uithoudingsvermogen je moet hebben om jarenlang met een strafzaak bezig te zijn? Ik heb toevallig gigantisch veel uithoudingsvermogen en ik ben ontiegelijk gedreven, maar ook ik denk op een gegeven moment: in godsnaam, neem al die slepende dossiers van me weg', aldus Bos. Ondertussen groeit de georganiseerde criminaliteit ons boven het hoofd.

\section{Een kwestie van uitvoering of een fundamenteel probleem?}

Als vonnissen en hogere straffen weinig oplossen en het strijdmodel evenmin uitkomst biedt, kampt de rechtspleging met een fundamenteel probleem. Dat los je niet op met een nieuw Wetboek van Strafvordering of versnelling van de doorlooptijden, noch met gesprekken tussen advocatuur, rechters en het OM over hoe de sfeer in de rechtszaal te verbeteren en het aantal wrakingen te verminderen. Zelfs meer geld voor politie, OM, rechtspraak en sociale advocatuur lijkt niet de weg. Want in het toernooimodel worden dossiers daar toch alleen maar dikker van?

Fundamentele verandering klinkt ingrijpend, maar in ons boek laten we zien dat de ontwikkeling al veel verder is dan velen denken. Tal van pilots, onderzoeken en nieuwe methoden zijn in ontwikkeling. We kunnen hier slechts de grote lijn schetsen.

Kijk naar de mishandelingen, dodelijke ongevallen, diefstallen, fraudes en zedendelicten waarover strafrechters dagelijks moeten vonnissen. Het loopt verkeerd tussen mensen door ongelukkig of misdadig gedrag, soms met desastreuze gevolgen, zoals bij het gezin Derijks, dat in één klap grootouders en kind verloor. Wie in zo'n situatie terechtkomt, wil meer dan een vonnis en een straf. Een slachtoffer wil weten wat er precies is gebeurd. Verdachten en slachtoffers hebben belang bij het in stand houden van hun sociale relaties en hun privacy. Voor mensen die iets misdaan hebben, en in de toekomst misschien nog een gevaar opleveren, wil de samenleving een veilige terugkeer in de maatschappij. Onrecht en sociale verhoudingen herstellen, angst wegnemen, verder kunnen met je leven, daar gaat het om.

Dat is terug te zien in de ZSM-aanpak (waarbij ZSM staat voor Zorgvuldig, Snel en op Maat), in de voorzieningen voor slachtoffers, in de op de persoon gerichte behandelplannen van de Wet straffen en beschermen en in de 'evidence based' aanpak van Reclassering Nederland. En ook in de herstelrechtbeweging, met nieuwe modellen voor strafrechtadvocatuur die daarop voortbouwen. Mediation in het strafrecht sluit aan bij wat wij in ons boek de behoefte aan rechtvaardige vrede noemen. Die ontstaat tussen mensen en in gesprek, hoe moeilijk dat ook kan zijn.

De rechter is daarvoor nog steeds essentieel, maar meer als bewaker van het goede gesprek dan als door wetten aangestuurde beslisser die an het einde van een lang 
proces een oordeel velt. De logische volgende stap is om de procedure voor de politierechter bij deze ontwikkelingen te laten aansluiten. De benadering van problem solving courts ligt daarvoor eigenlijk al klaar en wordt in steeds meer landen toegepast.

\section{Moet strafrecht wel zo heten?}

We noemden de roep om hogere straffen eerder een noodlottig misverstand. Mensen willen meer straf als dat het enige instrument is dat ze in handen krijgen. Leg je hun andere instrumenten voor, dan benutten ze die graag. Strafrecht lijkt nog steeds straffen als doel te hebben. De naam alleen al zet mensen op het spoor van sancties. Hoe kan het dat we hier collectief in blijven geloven? Dat ministers continu voorstellen blijven ontwikkelen met meer straf voor steeds meer delicten? In ons boek noemen we voorbeelden waar het huidige strafproces vooral een verwarrende en kostbare opvoering voor de bühne lijkt te zijn.

In de Wet straffen en beschermen zie je een onderliggende trend. ${ }^{1}$ Er komt een op de persoon gericht behandelplan, zodat mensen al tijdens hun straf gaan werken aan beheersing van agressie of verslaving. Ze kunnen voortaan ook na hun straf worden gevolgd en de rechter kan een gedragsbeinvloedende en vrijheidsbeperkende maatregel opleggen. Zo kan de rechter voorkomen dat mensen weer dicht bij hun slachtoffers gaan wonen of terugkeren in hun criminele vriendenkring. Wie niet aan behandeling meewerkt, krijgt minder voorzieningen en komt minder snel vrij. De trend is duidelijk: het opsluiten van mensen of het opleggen van een boete is niet langer een doel, maar een middel.

\section{Waar het naartoe gaat in de strijd tegen de georganiseerde misdaad}

Ook de burgemeesters, rechercheurs en officieren die ondermijnende criminaliteit bestrijden, werken aan nieuwe methodes. Politie en justitie brengen netwerken in kaart. Hoe verplaatsen de drugs zich, wie haalt wie over om tot de bende toe te treden, wat zijn de geldstromen, wat zijn de familierelaties en wie doet wat in de productie- en distributieketen?

De beste en meest rechtvaardige methoden van criminaliteitsbestrijding zouden centraal moeten staan in de juridische procedure. Die procedure zou kunnen beginnen met een uitgebreide reconstructie van het netwerk en de criminele activiteiten. Als een netwerk goed in

1. Staatsblad 2020, 224 kaart is gebracht en de informatie daarover publiek wordt gemaakt, stort een criminele organisatie in. Kopstukken krijgen het moeilijk als steeds minder mensen zaken met hen willen doen. Meelopers worden aangesproken door hun familie en hun vrienden. Door een kaart van het netwerk in een rechtszaal te bespreken, kan het effect van al dat onderzoek worden versterkt.

Rechters in Australië hebben al manieren ontwikkeld om dit soort grote onderzoeken in de rechtszaal te behandelen. Hot-tubbing noemen ze deze procedure. De rechter nodigt advocaten en experts uit om samen de vragen te formuleren die ze hebben over de resultaten en over de wijze van onderzoek. Vervolgens gaan ze die twijfels gezamenlijk bespreken. Een voor een worden de punten afgewerkt. Zo blijft de rechtszaak zich richten op de hoofdlijnen en is het verhaal beter te volgen voor alle betrokkenen. Een goede reconstructie voldoet bovendien aan een belangrijke behoefte van slachtoffers en het publiek: weten wat er is gebeurd en wie welke rol had.

Twijfel over de rol die individuen in criminele organisaties hadden, zal blijven bestaan. Soms zal dat ertoe leiden dat zij geen maatregelen krijgen opgelegd. Dan nog kunnen de uitkomsten positief zijn: netwerk ontmanteld, sleutelpersonen in kaart gebracht en activiteiten gestaakt, meldingen van slachtoffers drastisch verminderd, slachtoffers krijgen begeleiding en compensatie. Het kunnen klinkende resultaten zijn, die de rechter aan het einde van een procedure kan vaststellen. Het effectief oprollen van criminele netwerken is dan belangrijker dan iedere betrokkene individueel zijn gerechtvaardigde straf op te leggen. Zo'n manier van werken kan ook de samenwerking versterken tussen justitie en wat 'burgeronderzoek' heet. Denk aan de grote onderzoeken van journalisten, die steeds vaker in collectieven samenwerken, naar MH17 (Bellingcat), belastingontwijking (Panama Papers) en medische implantaten (The Implant Files).

\section{Liever geen debat maar samen onderzoeken}

Het recht is nu georganiseerd als een voortdurend debat op alle fronten. We kunnen beter stoppen met ons verder te verstrikken in allerlei regels die lang geleden zijn ontwikkeld. Het gaat niet helpen nog meer procedures aan het zo beroerd functionerende toernooimodel te plakken. Onderzoeken welke methodes werken en die op grote schaal mogelijk maken, dat is de meest belovende weg. Laten we de onderliggende trends volgen, zodat de professionals in de strafrechtketen in nieuwe rollen kunnen groeien, ondersteund door financiering en een wettelijke regeling. Juristen en criminaliteitsbestrijders verlangen naar recht dat werkt, aansluitend bij de behoeften aan veiligheid, rechtvaardigheid en vreedzaam verder kunnen leven. Dat is wat mensen van juristen vragen. Dat is menselijker recht. 